\title{
THE ROLE OF EFFLUX PUMP AND OTHER MECHANISMS OF ANTIMICROBIAL RESISTANCE TO (FLUORO)QUINOLONES IN EPIDEMIC ISOLATES OF SALMONELLA TYPHIMURIUM, SALMONELLA KENTUCKY AND SALMONELLA INFANTIS
}

Marina Arnaut ${ }^{1}$, Maja Velhner ${ }^{2 *}$, Ljiljana Suvajdžić ${ }^{3}$ Dubravka Milanov $^{2}$, Jelena Petrović ${ }^{2}$ and Gordana Kozoderović ${ }^{4}$

${ }^{1}$ Faculty of Sciences, Department of Biology and Ecology, University of Novi Sad, Serbia

${ }^{2}$ Scientific Veterinary Institute "Novi Sad", Novi Sad, Serbia

${ }^{3}$ Faculty of Medicine, Department of Pharmacy, University of Novi Sad, Serbia

${ }^{4}$ Faculty of Education in Sombor, Department of Natural Sciences and Mathematics, University of Novi Sad, Serbia

\section{Abstract}

This paper briefly describes mechanisms of resistance to fluoroquinolones in several worldwide distributed Salmonella clones. The isolates have acquired multiple resistance traits over the years due to extensive antibiotic treatment both in human and veterinary medicine. Except for the Salmonella Typhimuirum DT104 where efflux pump appears to play a major role in resistance to (fluoro)quinolones, in other serovars mutations on topoisomerase genes seem to firstly occur and have been primary mechanisms of resistance. Plasmid borne resistance is rarely detected but because of horizontal gene transfer needs to be recorded. Understanding the genetic events at the molecular level is crucial in epidemiology work and provides insight in spreading of resistance clones of Salmonella.

Key words: Salmonella Typhimuirum, Salmonella Kentucky, Salmonella Infantis, efflux pump, resistance, topoisomerase

\footnotetext{
${ }^{2 *}$ e-mail: maja@niv.ns.ac.rs
} 


\title{
ULOGA EFLUKS PUMPE I DRUGIH MEHANIZAMA REZISTENCIJE NA FLUORO(HINOLONE) KOD EPIDEMIOLOŠKIH IZOLATA \\ SALMONELLA TYPHIMURIUM, SALMONELLA KENTUCKY I SALMONELLA INFANTIS.
}

\author{
Marina Arnaut ${ }^{1}$, Maja Velhner ${ }^{2}$, Ljiljana Suvajdžićs ${ }^{3}$ Dubravka Milanov², \\ Jelena Petrović ${ }^{2}$, Gordana Kozoderović ${ }^{4}$ \\ ${ }^{1}$ Prirodnomatematički fakultet, Departman za biologiju i ekologiju, Novi Sad \\ ${ }^{2}$ Naučni institut za veterinarstvo "Novi Sad", Novi Sad \\ ${ }^{3}$ Medicinski fakultet, Departman za farmaciju, Novi Sad \\ ${ }^{4}$ Pedagoški fakultet, Sombor
}

\section{Kratki sadržaj}

U ovom radu kratko su opisani mehanizmi antimikrobne rezistencije na fluorohinolone kod nekoliko široko rasprostranjenih klonova Salmonela. Izolati su stekli multiplu rezistenciju tokom vremena usled prekomerne upotrebe antibiotika u humanoj i veterinarskoj medicini. Sa izuzetkom klona STDT104 kod kog efluks pumpa igra važnu ulogu u rezistenciji na FQ, drugi serotipovi rezistenciju primarno stiču mutacijama na topoizomeraznim genima. Plazmid posredovana rezistencija je retka kod Salmonela ali je izuzetno značajna zbog mogućnosti horizontalnog prenošenja gena. Razumevanje mehanizama rezistencije na molekularnom nivou je od vitalnog značaja u epidemiologiji zato što omogućava uvid u načine širenja klonova kod Salmonela.

Ključne reči: Salmonella Typhimuirum, Salmonella Kentucky, Salmonella Infantis, efluks pumpa, rezistencija, topoizomeraze

\section{INTRODUCTION}

Quinolone resistance and decreased susceptibility to fluoroquinolones in Salmonella arise as a consequence of treatment with antibiotics. Some of the most prominent and most frequent mechanisms of resistance of Salmonella are point mutations in quinolone resistance determining region (QRDR) of the gyrA gene. In Salmonella highly resistant to fluoroquinolones, mutations on $g y r B$, parC and parE genes have also been detected. The gyrA and gyrB genes encode GyraseA subunit, while parC and parE encode the topoisomerase 
IV. These enzymes are of vital importance for bacterial DNA transcriptional process. Screening of mutations is performed by PCR along with sequencing of the QRDR region to detect non-synonymous substitutions.

Another relevant mechanism of resistance to quinolones in Salmonella spp. is plasmid mediated, that arises by production of a small protein termed QNR. The QNR is characterized by pentapeptide repeats, composed of 218 amino acids and it preserves Gyrase from quinolone action, without the influence on the function of the enzyme. Plasmid borne QNR proteins are rarely found in isolates highly resistant to quinolones (Hopkins et al., 2005, Velhner et al., 2012) although Kehrenberg et al. (2006) have found qnrS gene in plasmid pINF5 of the $S$. Infantis obtaining MIC to NAL $512 \mathrm{mg} / \mathrm{L}$ indicating its strain specific occurrence.

Significant semi-specific mechanism of antimicrobial resistance in Salmonella is tripartite efflux pump AcrAB-TolC, classified as a member of Resistance Nodulation Division Family (RND) of transporters, and is responsible for extruding antimicrobial agents and other toxic substances out of the cell. It is usually involved in mediating multidrug resistance in bacteria as a nonspecific response since its primary evolutionary role has been to excrete bile salts from bacterial cell (Piddock 2006).

The AcrAB efflux pump is constituted of three proteins that form the channel in the cytoplasmic membrane. This system is energy dependent and subsequently regulated by active transport. Efflux pump consists of: periplasmic accessory protein (AcrA), transporter protein (AcrB) and the outer membrane protein (TolC), encoded by genes termed $a c r A, a c r B$ and tolC. The expression of the $A c r A B$ is fine tuned by several global and local activators and repressors, encoded by $a c r R$, $\operatorname{ram} A R$, sox $R S$ and marR $A B$ regulatory genes (Piddock LJV, 2006, Abouzeed et al. 2008, Giraud et al., 2013).

The overexpression of efflux genes occurs if local or global repressor genes are mutated. Two experiments are conducted to reveal these processes at molecular level. Firstly, the overexperssion experiments were aimed at showing increased level of the mRNA of activator efflux genes, applying qRT-PCR or dot blot technique with anti polyclonal antibodies. Further, the sequencing of local and global repressor genes is performed to determine sequence alterations compared to wild type, which are responsible for deactivation of repressor genes and subsequent overexpression of major efflux pump regulatory genes.

This paper briefly describes the role of efflux mechanism as well as target gene mutations and plasmid borne resistance to (fluoro)quinolones in Salmonella spp., which is one of the most important food borne pathogens worldwide. Several different fluoroquinolone resistant strains of Salmonella spp. have been detected by now and it is vital to determine their most im- 
portant antibiotic resistance mechanisms, since certain resistotypes are highly competitive in the conditions of extensive drug use.

Development of FQ resistance in Salmonella enterica serovar Typhimurium

Antibiotic susceptible Salmonella Typhimurium definite phage type 104 (STDT104) has been isolated from humans in England in 1960's. Multi-drug resistant STDT104 was firstly found in samples obtained from cattle in the UK in 1980 and in humans nine years later. Since then, STDT104 has spread worldwide and is considered an important pathogen in both human and veterinary medicine and it has been extensively studied over the years. This strain is multiple resistant to ampicillin (AMP), chloramphenicol (CHL), florfenicol (FLO), streptomycin (STR), spectinomycin (SPT), sulphonamides (SSS) and tetracyclines (TET). Resistance genes are clustered in salmonella genomic island 1 (SGI1) close to its 3'end. The SGI1 is located between thdF and int2 genes bounded by $18 \mathrm{~kb}$ inverted repeats and it has been determined that insertion has been driven by site specific recombination. (Cloeckaert and Schwarz, 2001, Carattoli et al., 2002, Doublet et al., 2005).

Since 1993, STDT104 in farm animals has also acquired additional mechanisms of resistance to quinolones due to the therapy with enrofloxacin. Resistance to quinolones and decreased fluoroquinolone susceptibility is primarily attributed to active efflux as well as to mutations on topoisomerase genes, mainly the gyrA gene (Giraud et al., 2000, Threlfall, 2000). Experiments on mutant cells produced by disruption of $a c r B$ gene or homologous recombination to obtain transformants with deleted tolC gene have shown that efflux mechanism plays an important role in resistance to quinolones but also to $\mathrm{CHO}$, FLO and TET. Baucheron et al. (2004) demonstrated that multiple drug resistance to TET, CHO, FLO is driven not only by overexpression of floR and $\operatorname{tet}(G)$ pump genes but is also highly dependent on AcrAB-TolC efflux system. Briefly, specific transporters Flo $(\mathrm{R})$ and $\operatorname{Tet}(\mathrm{G})$ deliver antibiotics from cytoplasmic membrane to the periplasm while AcrB recognize the substrate (antibiotic) and with TolC extrude the compounds out of the cell. Simultaneous action of both types of transporters induce higher levels of resistance to FLO, CHL and TET through cumulative effect of multicomponent AcrAB efflux pump and major facilitator superfamily (MFS) transporters.

During the period 1991-1995, highly ciprofloxacinresistant STDT204 var Copenhagen has been isolated from animals and humans in several countries and it was discovered that multiple point mutations on topoisomerase genes are associated with resistance to fluoroquinolones. The mutations were found on $g y r A$ Ser $83^{\circ}$ Ala, Asp $87^{\oplus}$ Asn, on $\operatorname{gyr} B$ Ser $464^{\circ} \mathrm{Phe}$ and on parC gene, Ser80 Ile (Heisig et al, 1995, Guerra et al., 2003). 
However, different isolates have shown different levels of MIC values of quinolones even in cases where isolates have carried identical mutations on topoisomerase genes. Decreased accumulation may in part account for decreased susceptibility and is mediated by overexpression of AcrABTolC efflux pump system. Additionally, in acrB inactivated mutants of the STDT204, the role of another efflux pump termed AcrEF has been discovered. AcrAB and AcrEF are characterized by high sequence homology and it appears that if $a c r B$ gene is deleted the expression of other efflux pump genes ( $a c r D$ and $a c r F)$ could potentially be increased. Also, the insertion sequences (IS 1 or IS10) were detected upstream of acrEF. These insertion sequences contain putative promoters and increase the expression of the acrEF genes while the expression of the putative local repressor acrS is not affected.

Subsequently it is believed that high resistance to fluoroquinolones in STDT 204 is developed by multiple target mutations on topoismerase genes as well as on global regulatory genes of efflux pump systems (Olliver et al., 2005, Giraud et al., 2006).

FQ resistance of Salmonella enterica serovar Kentucky is strain-specific.

During the period of five years (2000 - 2005) in France, Salmonella Kentucky ST198, CIPr (SKST198) was isolated from travelers who have returned from northeast and east Africa (Weill et al., 2006). In the year 2003, it caused nosocomial outbreaks in two hospitals in Slovakia and in 2005 it was isolated from a patient who returned to Belgium after visiting Libya. Since then, SKST198 has been sampled in Europe mostly from the travelers. In animals, $S$. Kentucky commonly infects poultry and turkey and these isolates usually harbor the resistance to (fluoro)quinolones (Le Hello et al., 2011, LeHello et al., 2013). Some strains feature salmonella genomic island 1 (SGI1), carrying class 1 integrons containing several antibiotic resistant gene cassettes. SGI1 is considered a non-replicative element, which integrates into a chromosome by recombination and it has been experimentally demonstrated that SGI1 could be conjugally transferred to recipient strain from chromosome to chromosome by a helper plasmid (Doublet et al., 2005). Several SGI1variants have been detected in S. Kentucky and subsequently labeled SGI1-A to - O. SGI1-K, P and Q variants are characterized by the presence of IS26 elements, which are often associated with antibiotic resistance genes and transposon structures which facilitate horizontal gene transfer among bacteria (Doublet et al. 2008). These particular mechanisms of genetic transfer and different integration patterns could possibly induce spread of one of the most important epidemic clones - SKST198.

The efflux mechanism in $S$. Kentucky has been studied by Baucheron et al., (2013). Out of 27 isolates collected from all over the world, the mutations on 
repressor ramR gene were found in only three of them. Function of RamR has been affected by the presence of frame shift GATC duplication, frame shift G insertion and $91 \mathrm{bp}$ deletions in the $\mathrm{ramR}$ gene. These genetic events induce 2 to 4 fold increase of resistance to fluoroquinolones due to increased expression of the AcrAB-TolC efflux system.

Monoclonal spread of Salmonella enterica serovar Infantis

Salmonella Infantis (SI) is most frequently found in broiler chickens and may present serious food contaminant. The presence of SI is usually recorded in farm animals (mainly poultry) and humans and it has become a very important pathogen worldwide. Moreover, similar or identical pulsotype and MLST (multi locus sequence type) has been described in studies from Japan (Shahada et, al., 2006), Israel (Gal More et al., 2010), Hungary (Nógrády et al., 2007), Germany (Hauser et al., 2012) and Serbia (Velhner et al., 2014). On the other hand, multidrug resistant SI subclone was identified in Germany and Hungary. It is believed that a clonal spread of a single clonal lineage has arisen as a result of a mechanisms, which protect the serovar from genetic rearrangements or horizontal gene transfer (Hauser et al., 2012).

Another mechanism of drug resistance of SI is plasmid mediated, obtained by the presence of qnrS gene (Kehrenberg et al., 2009). However, resistance to (fluoro)quinolones is mainly attributed to mutations on topoisomerase genes. Antimicrobial effect of fluoroquinolones arises as a result of interference with topoismerase enzymes thus preventing replication of bacterial genome. Mutation on topoismerase genes as well as the small protein QNR prevents binding of fluoroquinolone molecules to topoisomerase enzymes.

The role of active efflux was also documented in some strains of SI described by Velhner et al. (2014). Namely, eight SI isolates out of 64 harboring resistance to quinolones has shown 5-6 fold decrease in MIC concentration to NAL in the presence of Phe-Arg- $\beta$-Naphthylamide (PA $\beta N)$, efflux pump inhibitor (EPI). There is also evidence which implicate that overexpression of AcrABTolC efflux pump system may increase resistance to fluoroquinolones in SI.

The role of global regulators in expression of efflux pump in Salmonella was studied by Kehrenberg et al., (2009) in detail. The authors have developed in vitro mutants after exposing S. Infantis and several other serotypes to ciprofloxacin 1-128x of the MIC. MIC of the bacteria that have already shown resistance did not increase and no additional mutations compared to parent strain were found on topoisomerase genes. However, previously susceptible strains have developed mutations on gyrA and elevated MICs to NAL and CIP. In mutants obtained in vitro, mutational changes in regulatory genes of the efflux 
pump were detected on ramRA and soxRS. Increased expression of ramA (the activator gene) in $S$. Infantis (mutant 2) has arisen due to $10 \mathrm{bp}$ deletion that created early stop codon in $r a m R$ gene. Several other mutational types have been also detected in $r a m R$ gene and its flanking regions, causing the up-regulation of $\operatorname{ram} A$ gene and consequently overexpression of the efflux pump, in mutants of Salmonella serovars other than Typhimuirum.

Involvement of soxRS system in efflux genes expression in salmonella may not be very frequent but is very contributive fluoroquinolone resistance mechanism. It has been described in different Salmonella serovars, but the 49 bp insertion in soxR in $S$. Virchow 2 mutant (strain 1) generated an early stop codon at $\operatorname{soxR}$ gene, resulting in significantly higher upregulation of soxS than previously detected soxR mutations. Conclusively, upregulation of the AcrAB efflux system is highly dependent on slight alterations of expression of soxRS genes and may play important role in FQ resistance in Salmonella spp.

\section{ACKNOWLEDGMENT}

This work has been financially supported by a grant from Ministry of Education, Science and Technological Development, Republic of Serbia, Project number TR 31071.

\section{REFERENCES}

1. Abouzeed Y.M., Baucheron S., Cloeckaert A.: ramR mutations involved in efflux-mediated multidrug resistance in Salmonella enterica serovar Typhimurium. Antimicrob Agents Chemother, 52, 2428-2434, 2008.

2. Baucheron S., Tyler S., Boyd D., Mulvey M.R., Chaslus-Dancla E., Cloeckaert A.: AcrAB-TolC directs efflux-mediated multidrug resistance in Salmonella enterica serovar Typhimurium DT104, Antimicrob Agents Chemother, 48, 3729-3735, 2004.

3. Baucheron S., Le Hello S., Doublet B., Giraud E., Weill F.X., Cloeckaert A.: ramR mutations affecting fluoroquinolone susceptibility in epidemic multidrug-resistant Salmonella enterica serovar Kentucky ST198. Front Microbiol, 4, 1-6, 2013.

4. Caratolli A., Fietici E., Villa L., Dionisi M., Ricci A., Luzzi I.: Antibiotic resistance genes and Salmonella genomic island 1 in Salmonella enterica serovar Typhimuirum isolated in Italy. Antimicorb Agents Chemother, 46, 2821-2828, 2002.

5. Cloeckaert A., Schwarz S.: Molecular characterization, spread and evolu- 
tion of multidrug resistance in Salmonella enterica Typhimuirum DT104. Vet Res, 32, 301-310, 2001.

6. Doublet B., Boyd D., Mulvey M.R., Cloeckaert A.: The Salmonella genomic island 1 is an integrative mobilizable element. Mol Microbiol, 55, 19111924, 2005.

7. Doublet B., Praud K., Bertrand S., Collard J.M., Weill F.X., Cloeckaert A.: Novel insertion sequence and transposon-mediated genetic rearrangements in genomic island SGI1 of Salmonella enterica serovar Kentucky. Antimicorb Agents and Chemother, 52, 3745-3754, 2008.

8. Gal-Mor O., Valinsky L., Weinberger M., Guy S., Jaffe J., Schorr Y.I., Raisfeld A., Agmon V., Nissan I.: Multidrug-resistant S. enterica seorvar Infantis, Israel. Emerg Infecti Dis, 16, 1754- 1757, 2010.

9. Giraud E., Cloeckaert A., Kerboeuf D., Chaslus-Dancla E.: Evidence for active efflux as the primary mechanism of resistance to ciprofloxacin in Salmonella enterica serovar Typhimurium. Antimicrob Agents and Chemother, 44, 1223-1228, 2000.

10. Giraud E., Baucheron S., Cloeckaert A.: Resistance to fluoroquinolones in Salmonella: emerging mechanism and resistance prevention strategies. Microb Infect 8, 1937-1944, 2006.

11. Giraud E., Baucheron S., Virlogeux-Payant I., Nishino K., Cloeckaert A.: Effects of natural mutations in the ramRA locus on invasiveness of epidemic fluoroquinolone-resistant Salmonella enterica serovar Typhimuirum isolates. J Infect Dis 207, 794-802, 2013.

12. Guerra B., Malorny B., Schroeter A., Helmuth R.: Multiple resistance mechanisms in fluoroquinolone-resistant Salmonella isolates from Germany. Antimicrob Agents Chemother, 47-2059, 2003.

13. Hauser E., Tietze E., Helmuth R., Junker E., Prager R., Schroeter A., Rabsch W., Fruth A., Toboldt A., Malorny B.: Clonal dissemination of Salmonella enterica serovar Infantis in Germany. Foodborne Pathog Dis, 9, 352-360, 2012.

14. Heisig P., Kratz B., Halle E., Gräser Y., Altwegg M., Rabsch W., Faber JP:Identification of DNA Gyrase A mutations in ciprofloxacin-resistant isolates of Salmonella typhimuirum from men and cattle in Germany. Microb Drug Res, 1, 211-218, 1995.

15. Hopkins K.L., Davies R.H., Threlfall E.J.: Mechanisms of quinolone resistance in Escherichia coli and Salmonella: Recent developments. Int JAntimicrob Agents, 25, 358-373, 2005.

16. Kehrenberg C., Friederichs S., de Jong A., Brenner Michael G., Schwarz S.: Identification of the plasmid-borne quinolone resistance gene qnrS in Sal- 
monella enterica serovar Infantis. J Antimicrob Chemother, 58, 18-22, 2006.

17. Kehrenberg C., Cloeckaert A., Klein G., Schwarz S.: Decreased fluoroquinolone susceptibility in mutants of Salmonella serovars other than Typhimuirum: detection of novel mutations involved in modulated expression of ramA and soxS. J Antimicorb Chemother, 64, 1175-1180, 2009.

18. Le Hello, Hendriksen R.S., Doublet B., Fisher I., Møller Nielsen E., Whichard J.M., Bouchrif B., Fashae K., Granier S.A., Jourdan-Da Silva N., Cloeckaert A., Threlfall E.J., Angulo F.J., Aarestrup F.M., Wain J., Weill F.X.: International spread of an epidemic population of Salmonella enetrica serotype Kentucky ST198 resistant to ciprofloxacin. J Infect Dis, 204, 675-684, 2011.

19. Le Hello S., Bekhit A., Granier A., Barua H., Beutlich J., Zajac M., Münch S., Sintchenko V., Bouchrif B., Fashae K., Pinsard J.L., Sontag L., Fabre L., Garnier M., Guibert V., Howard P., Hendriksen R.S., Christensen J.P., Biswas P.K., Cloeckaert A., Rabsch W., Wasyl D., Doublet B., Weill F.X.: The global establishment of a highly-fluoroquinolone resistant Salmonella enterica serotype Kentucky ST198 strain. Front Microbiol, 4, 1-10, Article 395, 2013.

20. Nógrády N., Tóth A., Kostyák A., Pászti J., Nagy B.: Emergence of multidrug-resistant clones of Salmonella Infantis in broiler chickens and humans in Hungary. J Antimicrob Chemother, 60, 645-648,2007.

21. Olliver A., Vallé M., Chaslus-Dancla, Cloeckaert A: Overepression of the multidrug efflux operon acrEF by insertional activation with IS1 or IS10 elements in Salmonella enterica serovar Typhimurium DT204 acrB mutant selected with fluoroquinolones. Antimicorb Agents Chemother, 49, 289301, 2005.

22. Piddock L.J.V.: Clinically relevant chromosomally encoded multidrug resistance efflux pumps in bacteria. Clin Microbiol Rev, 19, 382-402, 2006.

23. Shahada F., Chuma T., Tobata K., Okamoto K., Sueyoshi M., Takase K.: Molecular epidemiology of antimicrobial resistance among S. enterica serovar Infantis from poultry in Kagoshima Japan, Int J Antimicrob Agents, 28, 302-307, 2006.

24. Threlfall E.J.: Epidemic Salmonella typhimuirum DT104 - a truly international multiresistant clone. J Antimicrob Chemother, 46, 7-10, 2000.

25. Velhner M., Kozoderović G., Jelesić Y., Stojanov I., Dubravka Potkonjak, Jelena Petrović: Plasmid mediated resistance to quinolones in Salmonella. Arhiv Vet Med, 5, 19-29, 2012

26. Velhner M., Kozoderović G., Grego E., Galić N., Stojanov I., Jelesić Z., Kehrenberg C.: clonal spread of Salmonella enterica serovar Infantis in Serbia: 
Acquisition of mutations on topoisomerase genes gyrA and parC leads to increased resistance to fluoroquinolones. Zoonoses Public Hlth, 6, 364370, 2014

27. Weill F.X., Bertrand S., Guesnier F., Baucheron S., Grimont P.A.D., Cloeckaert A.: Ciprofloxacin resistant Salmonella Kentucky in travelers. Emerg Infect Dis, 12, 1611-1612, 2006.

Primljeno: 20.07.2014.

Odobreno: 21.07.2014. 